\title{
Histamine induces ovulation in the isolated perfused rat ovary
}

\author{
G. Schmidt*§, Ch. Owman $\ddagger$ and N.-O. Sjöberg $\dagger$ \\ Department of Obstetrics and Gynecology at ${ }^{*}$ Helsingborg and $\dagger$ Lund and $\ddagger$ Department of Histology, \\ University of Lund, Lund, Sweden
}

\begin{abstract}
Summary. Ovulatory effects of histamine and specific antagonists were studied in isolated perfused ovaries from immature rats treated with 10 i.u. PMSG to stimulate follicular growth and maturation. Histamine alone, like $\mathrm{LH}$, induced ovulation in all ovaries tested, but the number of follicular ruptures was lower after histamine ( 7.0 and 2.2 ruptures, respectively, per ovary). The histamine-induced ovulations could be inhibited dose-dependently by the $\mathrm{H}_{1}$-receptor antagonist, pyrilamine, or the $\mathrm{H}_{2}$ antagonists, cimetidine and ranitidine. At the concentrations tested, these antagonists did not, when given separately, reduce the LH-induced ovulations significantly, but pyrilamine and cimetidine in combination lowered the ovulation frequency by $65 \%$. The prostaglandin synthesis inhibitor, indomethacin, was not able to block the histamine-induced ovulations.
\end{abstract}

\section{Introduction}

The ovarian content of histamine in the rat decreases after stimulation with luteinizing hormone (LH) or human chorionic gonadotrophin (hCG) (Szego \& Gitin, 1964; Hunter \& Leathem, 1968; Lipner, 1971). In rabbit and man the concentration is elevated before ovulation (Morikawa, Okamura, Okazaki \& Nishimura, 1976; Morikawa, Okamura, Takenaka, Morimoto \& Nishimura, 1981). Histamine, like LH, causes hyperaemia of the ovary (Wurtman, 1964) and the LH-induced increase in blood flow is prevented by antihistamines (Piacsek \& Huth, 1971). Such antagonists also reduce the number of released oocytes after hCG stimulation (Lipner, 1971), while histamine itself has the opposite effect (Batta, 1980). However, histamine is able to induce ovulation in the isolated rabbit ovary in the absence of gonadotrophin stimulation (Kobayashi, Wright, Santulli \& Wallach, 1983).

In the present study the possible role of histamine in the ovulation process and its interaction with LH was investigated in a recirculating system for perfusion of isolated rat ovaries by using selective antagonists for the histamine receptor subtypes, with the aim of characterizing in more detail the histaminergic effects on ovulation. We have previously shown that stimulation of the $\mathrm{H}_{1}$ subtype of receptor induces contraction of isolated smooth muscle strips from the walls of cow follicles, whereas relaxation is mediated by the $\mathrm{H}_{2}$-receptor (Schmidt, Kannisto, Owman \& Walles, 1986).

\section{Materials and Methods}

Animals. Immature female rats of the Sprague-Dawley strain (Anticimex, Stockholm, Sweden) were obtained at 20-21 days of age, and housed under controlled conditions with $14 \mathrm{~h}$ light 
$(05: 00-19: 00 \mathrm{~h})$ and $10 \mathrm{~h}$ darkness. They were fed a standard diet of pellets and water ad libitum. On the morning of Day 26, between 08:00 and 10:00 h, the rats were given s.c. 10 i.u. PMSG. This results in follicular growth and maturation within the next 2 days. On the morning of Day 28, before the endogenous LH surge which occurs between 15:00 and 18:00 h of that day (Ekholm \& Hillensjö, 1982), the animals were anaesthetized with pentobarbitone sodium i.p. (40 mg Mebumal/kg body wt: ACO, Solna, Sweden) for removal of the ovaries.

Operation procedure. The surgical technique for isolation of the ovaries was that described in detail by Koos, Jaccarino, Magaril \& LeMaire (1984) and Sogn, Abrahamsson \& Janson (1984). After injection of 100 i.u. heparin per animal (Heparin sodium, Kabi Vitrum, Stockholm, Sweden) into a tail vein, the abdomen was opened through a midline incision. One of the ovaries and its vessels were dissected free, together with the lumbar part of the aorta and the vena cava. The aorta and caval vein were separated from each other and cannulated with infusion catheters (Viggo, Helsingborg, Sweden) having outer diameters of 1.0 and $1.4 \mathrm{~mm}$, respectively. The ovary was then transferred to the perfusion system.

Perfusion system. The apparatus for perfusion of the rat ovaries was identical with that previously used in our laboratory for rabbit ovaries (Schmidt, Owman, Sjöberg \& Walles, 1985), and which was originally described by Janson et al. (1982). Three ovaries were simultaneously perfused in 3 identical closed perfusion systems containing $70 \mathrm{ml}$ Medium 199 with Earle's salts and L-glutamine (Gibco Bio-Cult, Paisley, U.K.). Bicarbonate $(0.026 \mathrm{M})$ was added to obtain $\mathrm{pH} 7.4$ when the medium was continuously oxygenated with a gas mixture of $95 \% \mathrm{O}_{2}+5 \% \mathrm{CO}_{2}$. The medium also contained $75 \mu \mathrm{g}$ benzylpenicillin $\mathrm{G} / \mathrm{ml}, 50 \mu \mathrm{g}$ streptomycin $/ \mathrm{ml}, 0 \cdot 2$ i.u. heparin $/ \mathrm{ml}, 0 \cdot 02$ i.u. insulin $/ \mathrm{ml}$, and $2 \%$ fatty acid-free bovine serum albumin (BSA, Sigma, St Louis, MO, U.S.A.).

The ovary with its pedicle was attached to the perfusion apparatus via the aortic catheter and placed in a separate glass beaker filled with warmed $\left(37^{\circ} \mathrm{C}\right)$ saline $(0.9 \%(\mathrm{w} / \mathrm{v}) \mathrm{NaCl})$. Initially, 1-2 $\mathrm{ml}$ medium were allowed to pass through the ovary into the beaker to rinse blood from the organ before the preparation was placed in the organ chamber. The perfusion pressure was adjusted in the different experiments to $70-90 \mathrm{mmHg}$, which resulted in a mean flow of $0.8 \mathrm{ml} / \mathrm{min}$, as checked by a specially designed outlet from the organ chamber. In each individual experiment the perfusion pressure and flow rate varied only within narrow limits because of the incorporated overflow system. After mounting, the ovary was allowed to accommodate during $1 \mathrm{~h}$ before the experiments started at about 12:00 h. Samples of medium $(2 \mathrm{ml})$ were taken hourly after the accommodation time until 24:00 h. Every sample was replaced with the same amount of fresh medium. The last sample was taken at $07: 00 \mathrm{~h}$ on the following morning, when the ovary was removed from the perfusion system and observed for follicular ruptures with the aid of a Zeiss OPM stereomicroscope at $\times 15-30$ total magnification. Identification of the rupture sites was facilitated during the microscopy by gentle perfusion of the ovary with $1 \%$ methylene blue through the arterial catheter. To recover the released oocytes, the medium from the organ chamber was transferred to centrifuge tubes together with the small amount of saline which was used to rinse the organ chamber thoroughly. The collected fluid was centrifuged at $1600 \mathrm{~g}$ for $5 \mathrm{~min}$ and the supernatant was aspirated until about $0.5 \mathrm{ml}$ remained. The content was examined on glass slides using transmitted light in a phase contrast microscope at $\times 80$ magnification.

Experimental. Perfusion of the excised ovaries started between 10:00 and 12:00 h. The ovaries, 5 in each group, were perfused according to 15 different experimental protocols as summarized in Table 1. Control ovaries received $0.1 \mathrm{ml}$ of a buffered solution of $\mathrm{KHCO}_{3}$ (see below) every hour until 24:00 h. In experiments with $\mathrm{LH}, 0 \cdot 1 \mu \mathrm{g} / \mathrm{ml}$ was added once after $1 \mathrm{~h}$ of perfusion. Histamine (giving an immediate concentration in the system of $5 \times 10^{-6} \mathrm{M}$ ) was added either every hour until 24:00 $\mathrm{h}$ in one of the groups or only twice after $1 \mathrm{~h}$ (histamine alone) or $2 \mathrm{~h}$ (antagonist followed by histamine) and $10 \mathrm{~h}$ perfusion in all other experimental groups with histamine. Each of the histamine receptor antagonists, cimetidine, ranitidine and pyrilamine, were administered every 
hour until 24:00 h. The concentrations referred to in Table 1 are the immediate distributed concentration at the respective interval of injection. Indomethacin was added to the medium after $1 \mathrm{~h}$ of perfusion (concentration in perfusion system, $10 \mu \mathrm{g} / \mathrm{ml}$ ), followed $1 \mathrm{~h}$ later by histamine administration.

Drugs. Ovine LH (batch NIAMMD-oLH-24: NIH, Bethesda, U.S.A.) was kindly provided by Professor K. Ahrén, Göteborg, Sweden. PMSG, histamine dihydrochloride and pyrilamine maleate were purchased from Sigma (St Louis, MO, U.S.A.), while cimetidine (Tagamet) was obtained from Smith, Kline and French, Hertfordshire, U.K. Indomethacin (Sigma) was made up as a suspension immediately before use in a buffered solution of $\mathrm{KHCO}_{3}$ at $\mathrm{pH} 7 \cdot 6$. All other substances were dissolved in $0.9 \%(\mathrm{w} / \mathrm{v}) \mathrm{NaCl}$.

Histamine assay. The concentration of histamine was determined in samples of perfusion medium, which was mixed with equal volumes of $3 \%$ trichloroacetic acid, followed by condensation with $o$-phthalaldehyde and subsequent fluorometric measurement at $355 / 440 \mathrm{~nm}$ wave length as described by Håkanson \& Rönnberg (1974). The sensitivity of the assay was $2 \mathrm{ng} / \mathrm{ml}$, with an intra-assay variation of less than $5 \%$.

Statistics. The number of ovulations per ovary was expressed as the mean value \pm s.e.m., and the significance level in the statistical comparison between mean values was calculated according to Student's $t$ test for unpaired observations.

\section{Results}

\section{General observations}

Flow rate and perfusion pressure did not change after the addition of histamine or $\mathrm{LH}$ to the perfusate. Both substances caused an oedematous swelling of the ovary, which was visible with the naked eye and in the stereomicroscope after about $3 \mathrm{~h}$. This oedema was not noticed in the control ovary.

Follicular ruptures began about $10 \mathrm{~h}$ after LH or histamine was added, but the exact time was not studied systematically. In the stereomicroscope the appearance of the ruptures was similar after induction with LH or histamine. The oocytes that were recovered in the morning at the end of the experiment were denuded or surrounded by granulosa cells. Some of the oocytes were degenerate but no attempt was made to determine the exact ratio, nor was the degree of oocyte maturation established because of the variation in time from ovulation until oocyte collection.

No ovulations occurred in the control group of ovaries perfused with buffer solution alone (Table 1, Group 1). All ovaries ovulated under the influence of LH (Group 2).

\section{Effect of histamine}

When histamine was added at hourly intervals to the perfusion system there was an accumulation of the amine in the circulating medium (Fig. 1). Histamine added twice to the medium during the experiment was sufficient to maintain a stable concentration in the perfusate (Fig. 1). Given alone, histamine induced ovulation in all ovaries (Table 1, Group 3) and there was no difference in the number of ovulations per ovary if the amine was added every hour (Group 3a) or twice (Group 3b) during the experiment. The frequency of ovulations was, however, significantly lower than for the LH induced ovulations (Group 2; $P<0.005$ ).

\section{Effect of an $H_{1}$-antagonist}

The lowest concentration of pyrilamine tested $\left(10^{-5} \mathrm{M}\right)$ had little or no effect on the histamineinduced ovulations (Table 1, Group 4a), whereas a 10 times higher concentration completely 
Table 1. Incidence of ovulation in isolated ovaries perfused in vitro after exposure to histamine $\left(5 \times 10^{-6} \mathrm{M}\right)$ or $\mathrm{LH}(0.1 \mu \mathrm{g} / \mathrm{ml})$ and the interaction with histamine antagonists and indomethacin

\begin{tabular}{|c|c|c|c|c|}
\hline Group & Treatment & $\begin{array}{c}\text { Ovaries } \\
\text { ovulating }\end{array}$ & $\begin{array}{l}\text { Ovulations } \\
\text { per ovary }\end{array}$ & $\begin{array}{c}\text { Significance } \\
\text { levels }\end{array}$ \\
\hline 1 & Vehicle & $0 / 5$ & 0 & \\
\hline 2 & LH & $5 / 5$ & $7.0 \pm 0.84$ & \\
\hline 3a & Histamine† & $5 / 5$ & $2 \cdot 3 \pm 0.61$ & 3a vs $2: P<0.005$ \\
\hline $3 \mathrm{~b}$ & Histamine & $5 / 5$ & $2 \cdot 2 \pm 0.58$ & $3 \mathrm{~b}$ ys $2: P<0.005$ \\
\hline $4 a$ & Pyrilamine $\left(1 \times 10^{-5} \mathrm{M}\right)+$ histamine & $4 / 5$ & $1.8 \pm 0.58$ & \\
\hline $4 \mathrm{~b}$ & Pyrilamine $\left(1 \times 10^{-4} \mathrm{M}\right)+$ histamine & $0 / 5$ & 0 & $4 \mathrm{~b}$ vs $3: P<0.02$ \\
\hline $5 \mathrm{a}$ & Pyrilamine $\left(1 \times 10^{-5} \mathrm{M}\right)+\mathrm{LH}$ & $5 / 5$ & $6 \cdot 6 \pm 1 \cdot 21$ & \\
\hline $5 b$ & Pyrilamine $\left(1 \times 10^{-4} \mathrm{M}\right)+\mathrm{LH}$ & $3 / 5$ & $3.4 \pm 1.53$ & \\
\hline $6 \mathrm{a}$ & Cimetidine $\left(3 \times 10^{-5} \mathrm{M}\right)+$ histamine & $5 / 5$ & $3.0 \pm 1.05$ & \\
\hline $6 \mathrm{~b}$ & Cimetidine $\left(1 \times 10^{-4} \mathrm{M}\right)+$ histamine & $1 / 5$ & $0.2 \pm 0.20$ & $6 \mathrm{~b}$ vs $3: P<0.02$ \\
\hline $6 \mathrm{c}$ & Cimetidine $\left(5 \times 10^{-4} \mathrm{M}\right)+$ histamine & $0 / 5$ & 0 & $6 \mathrm{c} v s 3: P<0.01$ \\
\hline $6 \mathrm{~d}$ & Ranitidine $\left(5 \times 10^{-4} \mathrm{M}\right)+$ histamine & $0 / 5$ & 0 & $6 \mathrm{~d} v s 3: P<0.01$ \\
\hline 7 & Cimetidine $\left(5 \times 10^{-4} \mathrm{M}\right)+\mathrm{LH}$ & $5 / 5$ & $4 \cdot 8 \pm 1 \cdot 20$ & \\
\hline 8 & Pyrilamine $\left(1 \times 10^{-4} \mathrm{M}\right)+$ & & & \\
\hline & cimetidine $\left(1 \times 10^{-4} \mathrm{M}\right)+\mathrm{LH}$ & $4 / 5$ & $2 \cdot 4 \pm 0.68$ & $8 v s 2: P<0.005$ \\
\hline 9 & Indomethacin $(10 \mu \mathrm{g} / \mathrm{ml})+$ histamine & $3 / 5$ & $1.0 \pm 0.45$ & \\
\hline
\end{tabular}

Values are mean \pm s.e.m., $n=5$ for all groups.

† Histamine was added every hour to the perfusate, from 10:00-12:00 h until 24:00 $\mathrm{h}$. In all other experiments with histamine, the amine was added at two occasions during the perfusion period (after 1 or $2 \mathrm{~h}$ and $10 \mathrm{~h}$ perfusion).

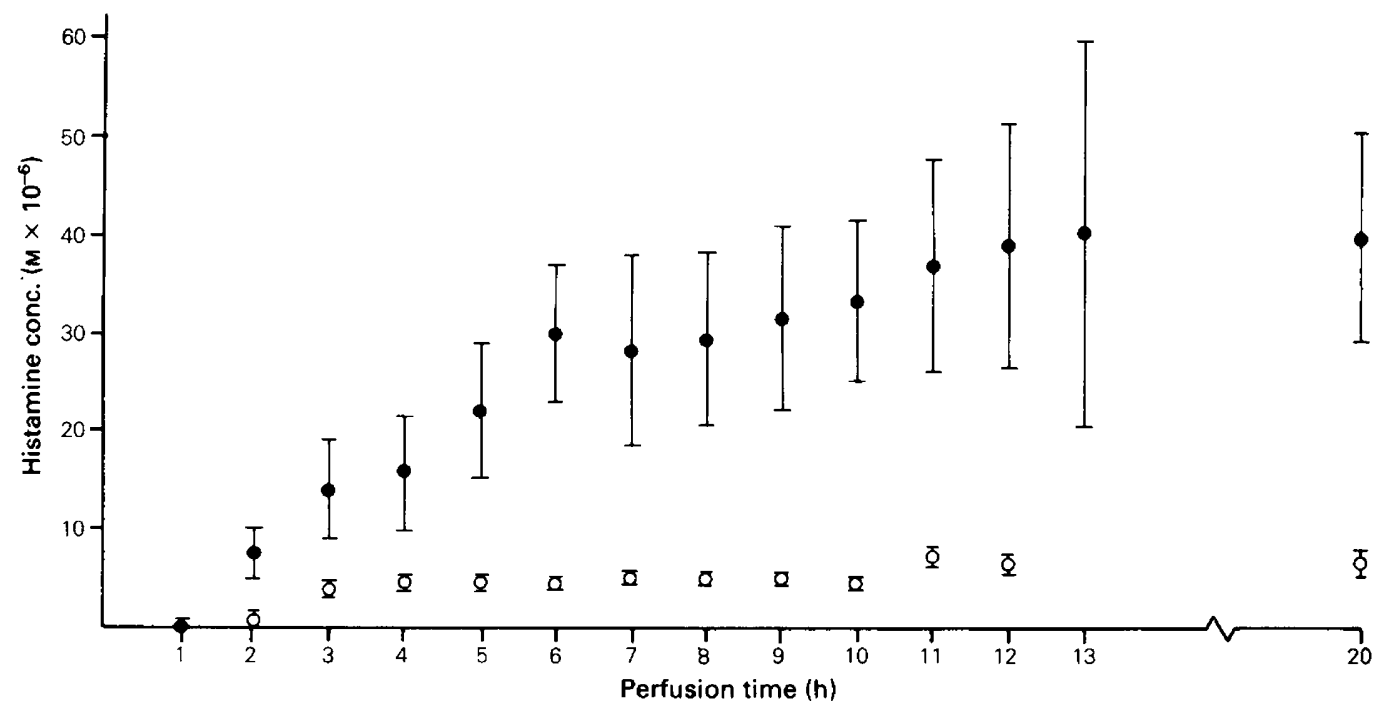

Fig. 1. Accumulation of histamine in the perfusate after adding histamine either every hour $(\bullet)$ or at only two intervals $(O)$ of $1 \mathrm{~h}$ and $10 \mathrm{~h}$ after the start of perfusion. Each dosage of histamine was sufficient by itself to create a concentration of $5 \times 10^{-6} \mathrm{M}$ in the perfusion fluid. Values are mean \pm s.e.m., $n=3$ for the multiple administration, and $n=5$ for the double administration.

blocked the effect of histamine (Group 4b). The ovulations induced by LH were not significantly affected by the lowest dose of pyrilamine (Group 5a), whereas the high dose tended to reduce the frequency, although the resultant ovulatory response was not significantly different from that of ovaries exposed to LH alone (Group 2). 
Effect of $\mathrm{H}_{2}$-antagonists

Cimetidine reduced the number of histamine-induced ovulations in a dose-dependent manner (Table 1, Group 6). At a concentration of $5 \times 10^{-4} \mathrm{M}$ in the medium a total block was accomplished (Group 6c). The same effect was seen with $5 \times 10^{-4} \mathrm{M}$-ranitidine (Group 6d).

The highest dose of cimetidine had no significant influence on the number of $\mathrm{LH}$-induced ovulations (Group 7).

\section{Combined effect of $\mathrm{H}_{1}$ - and $\mathrm{H}_{2}$-antagonists}

Pyrilamine $\left(10^{-4} \mathrm{M}\right)$ and cimetidine $\left(10^{-4} \mathrm{M}\right)$, present at the same time in the perfusate (Group $8)$, reduced the number of LH stimulated ovulations $(P<0 \cdot 005)$.

\section{Effect of indomethacin}

Of 5 ovaries exposed to histamine, 3 ovulated in the presence of indomethacin (Table 1, Group 9). The number of ruptures per ovary was not significantly reduced compared to ovaries receiving histamine alone (Group 3b).

\section{Discussion}

Immature rats injected with 10 i.u. PMSG at 26 days of age (Ekholm, Hillensjö \& Isaksson, 1981) were used to achieve a high number of ovulations in the perfusion system. This resulted in a mean of 7 ovulations per ovary with a range of $4-9$ ovulations, which is in the same order as the number of corpora lutea (8 per ovary) observed by Sogn et al. (1984) and the number of oocytes recovered in the oviduct (21 per animal) by Ekholm et al. (1981).

The concentration of BSA in the medium in previous in-vitro studies (Janson et al., 1982; Schmidt et al., 1985) has been $4 \%$. Albumin serves as a carrier protein for steroids and counteracts the formation of oedema and preserves the morphology in the ovary (Cajander et al., 1984). Since the oedema, the ovarian morphology, and the steroid release is the same for $2 \%$ and $4 \% \mathrm{BSA}$ (Sogn et al., 1984) the present experiments were performed with the lower concentration of BSA.

In the present experiments, histamine alone induced ovulations, with the present dose giving $30-40 \%$ of the ruptures induced by LH in the perfusion system (see also Koos et al., 1984). This agrees with the incidence found by Kobayashi et al. (1983), who also reported that follicle growth and rupture differed in rabbit ovaries exposed to histamine or LH: a characteristic apex or stigma was not present, and the oocytes often remained in an immature stage. Moreover, the action of histamine in the present study did not require an intact prostaglandin synthesis system, whereas indomethacin blocks the gonadotrophin-stimulated follicular rupture (Armstrong, 1981). Preliminary results from unpublished ongoing experiments have indicated that histamine does not potentiate the effect of $\mathrm{LH}$.

Specific effects of histamine are in general mediated by $\mathbf{H}_{1}$-receptors (Ash \& Schild, 1966) or $\mathrm{H}_{2}$-receptors (Black, Duncan, Durant, Ganellin \& Parsons, 1972). In the cow follicle wall, which contains smooth muscle cells in the theca externa layer (Walles et al., 1975), the $\mathrm{H}_{1}$ subtype of receptor is activated during contraction, whereas the $\mathrm{H}_{2}$-receptor is associated with relaxation of the wall (Schmidt et al., 1986). Strips from the human follicle wall respond to histamine to a greater extent in the ovulatory phase than during other times of the menstrual cycle (Morikawa et al., 1981). This conforms with observations that the spontaneous contractions of the rabbit ovary, which increase at the time of ovulation, can be completely blocked by the $\mathrm{H}_{1}$-receptor antagonist, chlorpheniramine (Virutamasen, Wright \& Wallach, 1972). Moreover, this antagonist has also been found to reduce hCG-induced ovulations in the rabbit ovary both in vivo (Knox \& Beck, 1976) and in vitro (Wallach, Wright \& Hamada, 1978). However, the in-vivo effect of chlorpheniramine could not be confirmed by Espey, Stein \& Dumitrescu (1982). 
The $\mathrm{H}_{2}$-receptor antagonist, cimetidine, appears to be unable to affect the hCG-induced ovulatory response of rabbits in vitro (Kobayashi et al., 1983) or in vivo (Espey et al., 1982). However, this antagonist, like chlorpheniramine, lowered the number of ovulations induced with histamine in the isolated perfused rabbit ovary (Kobayashi et al., 1983). The present experiments on rat ovaries agree with reports from studies on rabbits suggesting that the histamine-induced ovulation involves both receptor subtypes (Wallach et al., 1978; Kobayashi et al., 1983). The $\mathrm{H}_{2}$-receptor antagonism in our experiments was achieved with two kinds of selective antagonists of different chemical nature, cimetidine (Brogden, Heel, Speight \& Avery, 1978) and ranitidine (Brogden, Carmine, Heel, Speight \& Avery, 1982).

There may be several ways by which histamine affects the process of ovulation. The ovarian hyperaemia that follows LH or histamine stimulation (Wurtman, 1964) can be prevented by antihistamines (Piacsek \& Huth, 1971) and is reflected in an interstitial oedema (Bjersing \& Cajander, 1974). The increased permeability of perifollicular capillaries, with the appearance of fenestrations (Bjersing \& Cajander, 1974) and intercellular gaps between adjacent endothelial cells (Okuda, Okamura, Kanzaki \& Takenaka, 1983) as ovulation approaches, makes a free connection between the capillary lumen and the follicular antrum possible. This would increase the strain on the follicle wall already weakened and loosened by collagenolytic enzymes (Fukomoto, Yajima, Okamura \& Midorikawa, 1981) and prostaglandins (Espey, Coons, Marsh \& LeMaire, 1981; Dennefors et al., 1982).

In addition to its effect on permeability, histamine also has well-known actions on vascular resistance (see Owen, 1977; Tsuru, 1984): $\mathrm{H}_{2}$ - and $\mathrm{H}_{1}$-type of receptors may mediate vasodilatation. Harvey \& Owen (1979) found that the vasodilatory response in the reproductive tract of the rat was significantly reduced only after administration of $\mathrm{H}_{1}-$ and $\mathbf{H}_{2}$-receptor antagonists in combination. A histaminergic reduction of vascular resistance would thus assist in the above-mentioned extravasation reaction.

Since the relative importance of contractile and relaxing mechanisms in the follicle wall during the process of ovulation is not yet established, it is difficult to evaluate to what extent stimulation of the $\mathrm{H}_{1}$ - and $\mathrm{H}_{2}$-receptors in the wall are involved in the histaminergic action on ovulation. The follicle wall often contains numerous mast cells, usually present in the vicinity of local nerve terminals (Walles et al., 1975; Stefenson, Owman, Sjöberg, Sporrong \& Walles, 1981). It is not unlikely that activation of the follicular autonomic nerves, in addition to causing a direct contractile effect, also stimulates a release of histamine from the mast cells (Weisner-Menzel, Schultz, Vakilzadeh \& Czarnetski, 1981; Newson, Dahlström, Enerbäck \& Ahlman, 1983). Histamine from mast cells might influence follicular contractility either directly on its own, or through an interaction with the transmitter released from the nerve terminals (McGrath \& Shepherd, 1976; Foldes \& Hall, 1979; Suzuki \& Kou, 1983).

Histamine stimulates the formation of progesterone in preovulatory follicles (unpublished observations) dissected free from PMSG-stimulated prepubertal rat ovaries and incubated in a superfusion system (Hedin, Ekholm \& Hillensjö, 1983). Progesterone has been shown in some studies to increase the frequency of ovulation in vivo and in vitro (e.g. Takahashi, Ford, Yoshinaga \& Greep, 1974; Testart, Thébault \& Lefèvre, 1983), and histamine might influence the ovulatory process by stimulating the production of this sex steroid.

In conclusion, the observation that histamine receptor blockade lowered the incidence of LH-induced ovulations supports the view that this amine may be one of the mediators involved in the complex mechanism leading to follicular rupture under normal physiological conditions.

The study was supported by grants from the Swedish Medical Research Council (No. 14X-5680) the Faculty of Medicine, and AB Draco, Lund (Sweden). We thank Professor Rolf Håkanson, Department of Pharmacology, for generous help with the histamine determinations, and Ms Mary-Ann Sällström and Ms Britt Carlsson for skilful technical assistance. 


\section{References}

Armstrong, D.T. (1981) Prostaglandins and follicular functions. J, Reprod. Fert. 62, 283-291.

Ash, A.S.F. \& Schild, H.O. (1966) Receptors mediating some actions of histamine. Br. J. Pharmacol. 27, $427-439$.

Batta, S.K. (1980) Effect of histamine, phencyclidine, phenoxybenzamine and gamma-aminobutyric acid on ovulation and quality of ova in rats. Reproduccion 4, 99-107.

Bjersing, L. \& Cajander, S. (1974) Ovulation and the mechanism of follicle rupture. VI. Ultrastructure of theca interna and the inner vascular network surrounding rabbit Graafian follicles prior to induced ovulation. Cell Tissue Res. 153, 31-44.

Black, J.W., Duncan, A.M., Durant, C.J., Ganellin, C.R. \& Parsons, E.M. (1972) Definition and antagonism of histamine $\mathrm{H}_{2}$ receptors. Nature, Lond. 236, 385-390.

Brogden, R.N., Heel, R.C., Speight, T.M. \& Avery, G.S. (1978) Cimetidine: a review of its pharmacological properties and therapeutic efficacy in peptic ulcer disease. Drugs 15, 93-131.

Brogden, R.N., Carmine, A.A., Heel, R.C., Speight, R.M. \& Avery, G.S. (1982) Ranitidine: a review of its pharmacology and therapeutic use in peptic ulcer disease and other allied diseases. Drugs 24, 267-303.

Cajander, S., Janson, P.O., LeMaire, W.J., Källfelt, B.J., Holmes, P.V., Ahrén, K. \& Bjersing, L. (1984) Studies on the morphology of the isolated perfused rabbit ovary. I. Effect of long-term perfusion. Cell Tissue Res. 235, 59-63.

Dennefors, B., Tjugum, J., Norström, A., Janson, P.-O., Nilsson, L., Hamberger, L. \& Wilhelmsson, L. (1982) Collagen synthesis inhibition by $\mathrm{PGE}_{2}$ within the human follicular wall-one possible mechanism underlying ovulation. Prostaglandins 24, 295-302.

Ekholm, C. \& Hillensjö, T. (1982) LH-induced inhibition of follicular androgen formation requires intact steroidogenesis. Molec. cell. Endocrinol. 27, 67-75.

Ekholm, C., Hillensjö, T. \& Isaksson, O. (1981) Gonadotrophin releasing hormone agonists stimulate meiosis and ovulation in hypophysectomized rats. Endocrinology 108, 2022-2024.

Espey, L.L., Coons, P.J., Marsh, J.M. \& LeMaire, W.J. (1981) Effect of indomethacin on preovulatory changes in the ultrastructure of rabbit graafian follicles. Endocrinology 108, 1040-1048.

Espey, L.L., Stein, V.I. \& Dumitrescu, J. (1982) Survey of antiinflammatory agents and related drugs as inhibitors of ovulation in the rabbit. Fert. Steril. 38, 238-247.

Foldes, A. \& Hall, R.C. (1979) The effect of histamine on responses of the rabbit ear artery to electrical stimulation and to exogenous noradrenaline. $\mathrm{Br} . \mathrm{J}$. Pharmac. 67, 329-335.

Fukomoto, M., Yajima, Y., Okamura, H. \& Midorikawa, O. (1981) Collagenolytic enzyme activity in human ovary: an ovulatory enzyme system. Fert. Steril. 36, $746-750$.

Håkanson, R. \& Rönnberg, A.-L. (1974) Improved fluorometric assay of histamine: condensation with $o$-phthalaldehyde at $-20^{\circ} \mathrm{C}$. Analyt. Biochem. 60, $560-567$.

Harvey, C.A. \& Owen, D.A.A. (1979) Effect of histamine on uterine vasculature in rats. Eur. J. Pharmacol. 56, 293-296.

Hedin, L., Ekholm, C. \& Hillensjö, T. (1983) Doserelated effects of luteinizing hormone on the pattern of steroidogenesis and cyclic adenosine monophosphate release in superfused preovulatory rat follicles. Biol. Reprod. 29, 895-904.

Hunter, F. \& Leathem, J.H. (1968) Histamine concentrations in normal and cystic rat ovaries. Endocrinology 82, 171-172.

Janson, P.O., LeMaire, W.J., Källfelt, B., Holmes, P.V., Cajander, S., Bjersing, L., Wiqvist, N. \& Ahrén, K. (1982) The study of ovulation in the isolated perfused rabbit ovary. I. Methodology and pattern of steroidogenesis. Biol. Reprod. 26, 456-465.

Knox, G.E. \& Beck, L.R. (1976) Prevention of ovulation in rabbits by antihistamine. Gynecol. Invest. 7, 30-31.

Kobayashi, Y., Wright, K.H., Santulli, R. \& Wallach, E.E. (1983) Effect of histamine and histamine blockers on the ovulatory process in the in vitro perfused rabbit ovary. Biol. Reprod. 28, 385-392.

Koos, R.D., Jaccarino, F.J., Magaril, R.A. \& LeMaire, W.J. (1984) Perfusion of the rat ovary in vitro: methodology, induction of ovulation and pattern of steroidogenesis. Biol. Reprod. 30, 1135-1141.

Lipner, H. (1971) Ovulation from histamine depleted ovaries. Proc. Soc. exp. Biol. Med. 136, 111-114.

McGrath, M.A. \& Shepherd, J.T. (1976) Inhibition of adrenergic neurotransmission in canine vascular smooth muscle by histamine. Circ. Res. 39, 566-573.

Morikawa, H., Okamura, H., Okazaki, T. \& Nishimura, T. (1976) Changes of histamine in rabbit ovary during ovulation. Acta obstet. gynecol. jap. 28, 504-508.

Morikawa, H., Okamura, H., Takenaka, A., Morimoto, K. \& Nishimura, T. (1981) Histamine concentration and its effect on ovarian contractility in humans. Int. J. Fertil. 26, 283-286.

Newson, B., Dahlström, E., Enerbäck, L. \& Ahlman, H. (1983) Suggestive evidence for a direct innervation of mucosal mast cells. Neuroscience 10, 565-570.

Okuda, Y., Okamura, H., Kanzaki, H. \& Takenaka, A. (1983) Capillary permeability of rabbit ovarian follicles prior to ovulation. J. Anat. 137, 263-269.

Owen, D.A.A. (1977) Histamine receptors in the cardiovascular system. Gen. Pharmacol. 8, 141-156.

Piacsek, B.E. \& Huth, J.F. (1971) Changes in ovarian venous blood flow following cannulation; Effects of luteinizing hormone (LH) and antihistamine. Proc. Soc. exp. Biol. Med. 138, 1022-1024.

Schmidt, G., Owman, Ch., Sjöberg, N.-O. \& Walles, B. (1985) Influence of adrenergic agonists and antagonists on ovulation in the rabbit ovary perfused in vitro. J. Autonom. Pharmacol. 5, 241-250.

Schmidt, G., Kannisto, P., Owman, Ch. \& Walles, B. (1986) Characterization of histamine receptors mediating contraction and relaxation of the ovarian follicle wall. Int. J. Fertil. (in press).

Sogn, J., Abrahamsson, G. \& Janson, P.O. (1984) Release of cyclic-AMP and progesterone from the isolated perfused luteal ovary of the PMSG-treated rat. Acta endocr. Copenh. 106, 265-270. 
Stefenson, A., Owman, Ch., Sjöberg, N.-O., Sporrong, B. \& Walles, B. (1981) Comparative study of the autonomic innervation of the mammalian ovary with particular regard to the follicular system. Cell Tissue Res. 215, 47-62.

Suzuki, H. \& Kou, K. (1983) Direct and indirect effects of histamine on the smooth muscle cells of the guineapig main pulmonary artery. Pflugers Arch. ges. Physiol. 399, 46-53.

Szego, C.M. \& Gitin, E.S. (1964) Ovarian histamine depletion during acute hyperaemic response to luteinizing hormone. Nature, Lond. 201, 682-684.

Takahashi, M., Ford, I., Yoshinaga, I. \& Greep, R.O. (1974) Induction of ovulation in hypophysectomized rats by progesterone. Endocrinology 95, 1322-1326.

Testart, I., Thébault, A. \& Lefèvre, B. (1983) In vitro ovulation of rabbit ovarian follicles isolated after the endogenous gonadotrophin surge. J. Reprod. Fert. 68, $413-418$.

Tsuru, H. (1984) Histamine receptors in the cardiovascular system. Biblthca Cardiol. 38, 70-80.

Virutamasen, P., Wright, K.H. \& Wallach, E.E. (1972) Effect of catecholamines on ovarian contractility in the rabbit. Obstet. Gynecol. 39, 225-236.
Wallach, E.E., Wright, K.H. \& Hamada, Y. (1978) Investigation of mammalian ovulation with an in vitro perfused rabbit ovary preparation. $A m$. $J$. Obstet. Gynecol. 132, 728-738.

Walles, B., Edvinsson, L., Falck, B., Owman, Ch., Sjöberg, N.-O. \& Svensson, K.-G. (1975) Evidence for neuromuscular mechanism involved in the contractility of the ovarian follicular wall: fluorescence and electronmicroscopy and effects of tyramine on follicle strips. Biol. Reprod. 12, 239-248.

Weisner-Menzel, L., Schultz, B., Vakilzadeh, F. \& Czarnetski, B.M. (1981) Electron microscopical evidence for a direct contact between nerve fibres and mast cells. Acta dermatovenerol. 61, 465-469.

Wurtman, R.J. (1964) An effect of luteinizing hormone on the fractional perfusion of the rat ovary. Endocrinology 75, 927-933.

Received 17 December 1985 